\title{
Erratum: The cancer vaccine roller coaster
}

\section{Bruce Goldman \& Laura DeFrancesco}

Nat. Biotechnol. 27, 129-139 (2009); published online 7 February 2009; corrected after print 7 June 2010

In the version of this article initially published, the Mologen product description in Table 5, page 139, was incomplete and its status incorrectly stated to be compassionate use in India. The product description should have read: Genetically modified allogeneic (human) tumor cells for the expression of IL-7, GM-CSF, CD80 and CD154, in fixed combination with a DNA-based double stem loop immunomodulator (dSLIM). The status should have read: Orphan drug status granted by EMEA in 2006. The error has been corrected in the HTML and PDF versions of the article.

\section{Erratum: Irish bioethics council axed}

\section{Cormac Sheridan}

Nat. Biotechnol. 28, 112 (2010); published online 5 February 2010; corrected after print 7 June 2010

In the version of this article initially published, a researcher at University College Cork was incorrectly named. His name is Tom (not Barry) Moore. The error has been corrected in the HTML and PDF versions of the article.

\section{Erratum: Never again}

\section{Chris Scott}

Nat. Biotechnol. 28, 131 (2010); published online 5 February 2010; corrected after print 7 June 2010

In the version of this article initially published, Art Levinson is incorrectly described as a founder of Genentech, Sandra Horning as senior vice president of global clinical development and Richard Scheller as chief of operations. Their titles should have read: CEO Arthur Levinson moved up to the board of directors.... Sandra Horning...took over as senior vice president, global head, clinical development, hematology/oncology. Executive vice president, research, Richard Scheller... The errors have been corrected in the HTML and PDF versions of the article.

\section{Erratum: Resuscitated deCODE refocuses on diagnostics}

\section{Mark Ratner}

Nat. Biotechnol. 28, 192 (2010); published online 8 March 2010; corrected after print 7 June 2010

In the version of this article initially published, it was reported that deCODE had "shuttered its Emerald Biosciences and Emerald Biostructures drug discovery operations"; in fact, the companies were sold to investors. In addition, the correct name of Emerald Biosciences is Emerald BioSystems. The error has been corrected in the HTML and PDF versions of the article.

\section{Erratum: Biotech in a blink}

\section{Ken Garber}

Nat. Biotechnol. 28, 311-314 (2010); published online 8 April 2010; corrected after print 15 April 2010

In the version of the article originally published, Michael Tolentino was misquoted to the effect that bevasiranib had been shown to persist indefinitely in post-mitotic cells. Tolentino actually stated that the RNA-induced signaling complex persists. The error has been corrected in the HMTL and PDF versions of the article. 